\title{
PREVALENCE AND DETERMINANTS OF HEMOGLOBIN VARIABILITY AND ITS IMPACT ON MORTALITY IN PATIENTS ON MAINTENANCE HEMODIALYSIS
}

\author{
Zorica Dimitrijević1,2, Branka Mitić1,2, Karolina Paunović1 ${ }^{1}$, Sonja Šalinger-Martinović ${ }^{2}$
}

\begin{abstract}
Treatment with erythropoiesis-stimulating agents (ESA) is the optimal therapy for renal anemia. However, maintaining hemoglobin $(\mathrm{Hb})$ within narrow targets remains a significant clinical problem because during ESA treatment, the $\mathrm{Hb}$ levels usually fluctuate widely; this phenomenon is termed "hemoglobin variability" and is associated with higher mortality. Our study aimed to determine the prevalence and cause of hemoglobin variability in patients on chronic hemodialysis (HD) treatment and to estimate the association of $\mathrm{Hb}$ variability with all-cause mortality.

A prospective study was conducted on 193 chronic HD patients treated with ESA. Hemoglobin cycling was defined as $\mathrm{Hb}$ variability throughout at least eight weeks and amplitude of more than $1.5 \mathrm{~g} / \mathrm{dl}$ from the Serbian target range of $10-11 \mathrm{~g} / \mathrm{dl}$.

During the one-year follow-up, there was 5.6 ESA dose modification per patient. $23.4 \%$ of patients had never experienced $\mathrm{Hb}$ cycling during the study period. The total number of 460 hemoglobin excursions were recorded in $76.6 \%$ of patients, with $2.42 \pm 2.7 \mathrm{Hb}$ excursions per year, mean amplitude of $2.13 \pm 0.76 \mathrm{~g} / \mathrm{dL}$, and the average length of $\mathrm{Hb}$ excursion of $8.2 \pm 2.7$ weeks. The $\mathrm{Hb}$ cycling was not affected by the gender, age, weekly ESA dose, or the presence of diabetes or hypertension. However, $\mathrm{Hb}$ variability was associated with ESA dose change, $\mathrm{CRP}$, and HD vascular access type. The odds ratio for 1-year all-cause mortality was 1.424 (95\% CI: $1.231-1.682$, P < 0.001).

Hemoglobin cycling frequently occurs in ESA treated HD patients as a result of current practice in ESA dosing, the presence of infection, and the type of vascular access for HD and these fluctuations predicted overall mortality.
\end{abstract}

Acta Medica Medianae 2020;59(1):05-13.

Key words: hemoglobin variability, erythropoiesis-stimulating agents, hemodialysis

${ }^{1}$ Clinic of Nephrology, Clinical Center Niš, Niš, Serbia

${ }^{2}$ University of Niš, Faculty of Medicine, Niš, Serbia

Contact: Zorica Dimitrijević, Njegoševa 52, 18000 Niš, Serbia E-mail: zorica_mdimitrijevic@yahoo.com

\section{Introduction}

Anemia is a common complication that is associated with adverse cardiovascular complications and poor outcomes in patients with chronic kidney disease (CKD) (1). The introduction of erythropoiesis-stimulating agents (ESA) has revolutionized the management of anemia in CKD, leading to substantial reductions in the blood transfusion requirements, improvement in energy, and physical function (2) and improvements in health-related quality of life
(3). Even though the optimal target hemoglobin $(\mathrm{Hb})$ concentration in hemodialysis (HD) patients continues to be a substantial dilemma, the European Best Practice Guidelines (EBPG) recommended that the target hemoglobin level should be determined on an individual basis, having in mind gender, age, ethnicity, activity, and comorbid conditions (4). Nevertheless, with the publication of CREATE and CHOIR studies, both the upper and lower limits for target $\mathrm{Hb}$ concentration was set to $10-12 \mathrm{~g} / \mathrm{dL}(5,6)$ as it was shown that targeting normal $\mathrm{Hb}$ levels did not result in better survival, but rather in increased cardiovascular events and mortality in HD patients. Keeping patients' $\mathrm{Hb}$ levels in such a narrow range is difficult considering the loss of physiological regulation of red cell generation and many other factors, such as iron deficiency, chronic inflammation, secondary hyperparathyroidism, malnutrition, and inadequate dialysis dose. The data confirm that only $30 \%$ of patients will belong to this hemoglobin range at any point in time because fluctuations in the $\mathrm{Hb}$ level result in frequent under-and overreaching the target level (7). This phenomenon is known as $\mathrm{Hb}$ 
variability, and it is defined as repeated, cyclical, up and down movements of absolute $\mathrm{Hb}$ levels during ESA treatment. It is speculated that $\mathrm{Hb}$ variability may influence patients' survival. A few authors hypothesized that $\mathrm{Hb}$ variability increase mortality risk since fluctuations in $\mathrm{Hb}$ might affect oxygen delivery to tissues, thereby resulting in end-organ damage. Over the last decade, significant consideration has been given to the variability in $\mathrm{Hb}$ levels for dialysis patients. Several population-based studies investigating $\mathrm{Hb}$ fluctuation have been performed to date, but the results are controversial (7-10).

The aims of the study were to assess the prevalence and causes of $\mathrm{Hb}$ variability in hemodialysis patients and to estimate all-cause mortality depending on hemoglobin cycling in light of the Serbian regulatory restrictions in renal anemia management with lower target hemoglobin range of $10-11 \mathrm{~g} / \mathrm{d}$.

\section{Patients and methods}

This prospective study was carried out at the Nephrology Clinic of the Clinical Center Niš, Serbia from January 2015 to February 2016. The study was conducted in accordance with the Declaration of Helsinki for medical research. We included 193 stable patients over 18 years with end-stage renal disease who have been undergoing treatment with repeated hemodialysis for longer than three months. Patients with acute illness, malignancy, or active inflammatory diseases were excluded.

Baseline data including demographic characteristics, dialysis vintage, dialysis parameter (Kt/V), anthropometric parameters (body height, body weight), dose, type and regimen of ESA, hematological, and biochemical analyses as well as data on selected comorbidities. Hematological parameters were analyzed on Nihon Kohden Hematology Analyzer; biochemical data were measured on Siemens Dimension RXL Max Chemistry Analyser while serum measurement of PTH was done on Roche Cobas e411.

During the study period, anemia syndrome was corrected by subcutaneously applied ESA, which was used according to the current recommendations of the European Best Practice Guidelines and Health Insurance Fund of Serbia's policy for renal anemia treatment in HD patients. The nursing staff administered ESA into the left or right upper arm during the regular hemodialysis sessions. As intravenous ESA application requires higher doses, all our patients were on a subcutaneous dosing regimen.

Erythropoiesis-stimulating agents were started when the $\mathrm{Hb}$ level was below $10 \mathrm{~g} / \mathrm{dL}$. The starting and maintenance doses of erythropoietin alpha/ beta were $50-150$ and $25-75 \mu / \mathrm{kg} /$ week and of darbepoetin $0.25-0.75$ and $0.13-0.35 \mu / \mathrm{kg} /$ week. The erythropoiesis-stimulating agent was stopped after achieving an $\mathrm{Hb}$ level of $11 \mathrm{~g} / \mathrm{dL}$. Two hundred units of r-HuEPO is equivalent to $1 \mu \mathrm{g}$ of darbepoetin, so we converted darbepoetin unit accordingly.

Initially, rHuEPO was administered three times a week to achieve target concentrations of $\mathrm{Hb} 10-11$ $\mathrm{g} / \mathrm{dL}$ while maintaining the obtained target $\mathrm{Hb}$ levels by an individual approach (hold, keep unchanged, increase or decrease the dose on a monthly basis). ESA therapy was stopped when hemoglobin level reached $12 \mathrm{~g} / \mathrm{dl}$. Intravenous iron sucrose was prescribed if ferritin was $<100 \mu \mathrm{g} / \mathrm{L}$, or the transferrin saturation (TSAT) was $<20 \%$, and $\mathrm{Hb}$ was below the target range. Patients received $100 \mathrm{mg}$ intravenously over each of the next $10 \mathrm{HD}$ treatments, and then every two weeks thereafter. Iron was withheld if ferritin was $>800 \mu \mathrm{g} / \mathrm{L}$, or the TSAT was $>50 \%$.

As per Fishbane and Berns (11), hemoglobin variability characterizes the fluctuation of hemoglobin above or below the target range over time. In our study group, $\mathrm{Hb}$ cycling was defined as an oscillation in $\mathrm{Hb}$ of $\geq 1.5 \mathrm{~g} / \mathrm{dl}$ over $>8$ weeks during which $\mathrm{Hb}$ levels increased or decreased and then reversed the initial trajectory in relation to target $\mathrm{Hb}$ of $10-11 \mathrm{~g} / \mathrm{dL}$. Patients were divided into two groups: without $\mathrm{Hb}$ fluctuation and with $\mathrm{Hb}$ fluctuation. The outcome measure was all-cause mortality during the twelve months follow-up.

The following laboratory parameters were monitored over the period of 12 months after inclusion: hemoglobin ( $\mathrm{Hb}-\mathrm{g} / \mathrm{L})$ monthly, hemodialysis dose (KT/V), TSAT (\%), C-reactive protein (CRP$\mathrm{mg} / \mathrm{L})$, ferritin $(\mathrm{ng} / \mathrm{ml})$ and serum albumin $(\mathrm{g} / \mathrm{L})$ at 3 months and parathyroid hormone (PTH-pg/ml) at 6 months prior to the mid-week hemodialysis session in the first week of the month. TSAT was calculated as the ratio of serum iron to total iron-binding capacity (TIBC). All laboratory values were measured by automated and standardized methods.

\section{Statistical analysis}

Continuous variables were presented as mean \pm standard deviation (SD), and categorical variables were presented as number $(\mathrm{N})$ or percentage (\%). The Student's t-test was used to compare two groups of data (if there is a normal distribution of frequencies within the group), or the non-parametric Mann-Whitney Rank Sum test is used if the frequency distribution is uneven. Logistic regression analysis was performed to identify independent risk factors for $\mathrm{Hb}$-variability. A Kaplan-Meier analysis was used to examine the effects of hemoglobin variability on all-cause mortality. P-value $<0.05$ was considered as statistically significant. Statistics were generated using SPSS version 21.

\section{Results}

The study included 193 stable ESRD treated with hemodialysis. The mean age of the patients was $63.88 \pm 12.51$ years, $61.1 \%$ of patients were male, dry weight was $64.3 \pm 12.8 \mathrm{~kg}$, and dialysis vintage was $66.67 \pm 55.18$ (range 14.9-284.1) months. Most of the patients (71.1\%) suffered from hypertension, and $25.90 \%$ from diabetes. The characteristics of the participants are summarized in Table 1. 
Table 1. Basic demographic, hemodynamic, anthropometric and biochemical characteristics of the HD subjects treated with ESA

\begin{tabular}{|c|c|}
\hline Age (years) & $63.88 \pm 12.51$ \\
\hline Men (\%) & $118(61.1 \%)$ \\
\hline Dialysis vintage (months) & $66.67 \pm 55.18$ \\
\hline Arteriovenous fistula (\%) & 81.2 \\
\hline $\mathrm{Kt} / \mathrm{V}$ & $1.35 \pm 0.64$ \\
\hline Dry weight (kg) & $64.3 \pm 12.8$ \\
\hline Interdialtic weight gain (kg) & $2.9 \pm 2.3$ \\
\hline Body Mass Index $\left(\mathrm{kg} / \mathrm{m}^{2}\right)$ & $25.1 \pm 3.2$ \\
\hline Systolic blood pressure $(\mathrm{mmHg})$ & $135.2 \pm 30.9$ \\
\hline Diastolic blood pressure $(\mathrm{mmHg})$ & $91.7 \pm 13.1$ \\
\hline Hypertension (\%) & $135(71.1 \%)$ \\
\hline Diabetes mellitus (\%) & $50(25.90 \%)$ \\
\hline $\mathrm{Hb}(\mathrm{g} / \mathrm{l})$ & $103.17 \pm 5.04$ \\
\hline Iron $(\mathrm{mmol} / \mathrm{l})$ & $13.7 \pm 12.9$ \\
\hline TIBC $(\mu \mathrm{mol} / \mathrm{L})$ & $38.7 \pm 20.4$ \\
\hline Transferrin saturation (\%) & $32.6 \pm 10.6$ \\
\hline Ferritin (ng/mL) & $246.1 \pm 135.8$ \\
\hline Cholesterol (mmol/l) & $4.9 \pm 1.5$ \\
\hline Triglycerides $(\mathrm{mmol} / \mathrm{l})$ & $2.6 \pm 1.9$ \\
\hline LDL-C (mmol/l) & $3.1 \pm 0.4$ \\
\hline $\mathrm{HDL}-\mathrm{C}(\mathrm{mmol} / \mathrm{l})$ & $1.6 \pm 0.9$ \\
\hline s. Albumins $(\mathrm{g} / \mathrm{l})$ & $32.07 \pm 4.37$ \\
\hline Total protein $(\mathrm{g} / \mathrm{l})$ & $66.78 \pm 7.54$ \\
\hline s. Creatinine $(\mu \mathrm{mol} / \mathrm{l})$ & $809.64 \pm 356.22$ \\
\hline $\mathrm{CRP}(\mathrm{mg} / \mathrm{l})$ & $9.96 \pm 7.55$ \\
\hline PTH (pg/ml) & $446.30 \pm 294.81$ \\
\hline
\end{tabular}

Abbreviation: $\mathrm{Hb}$, hemoglobin; TIBC-total iron binding capacity; LDL-C, low density cholesterol; HDL-C,high density cholesterol; CRP, C-reactive protein; PTH, parathormone.

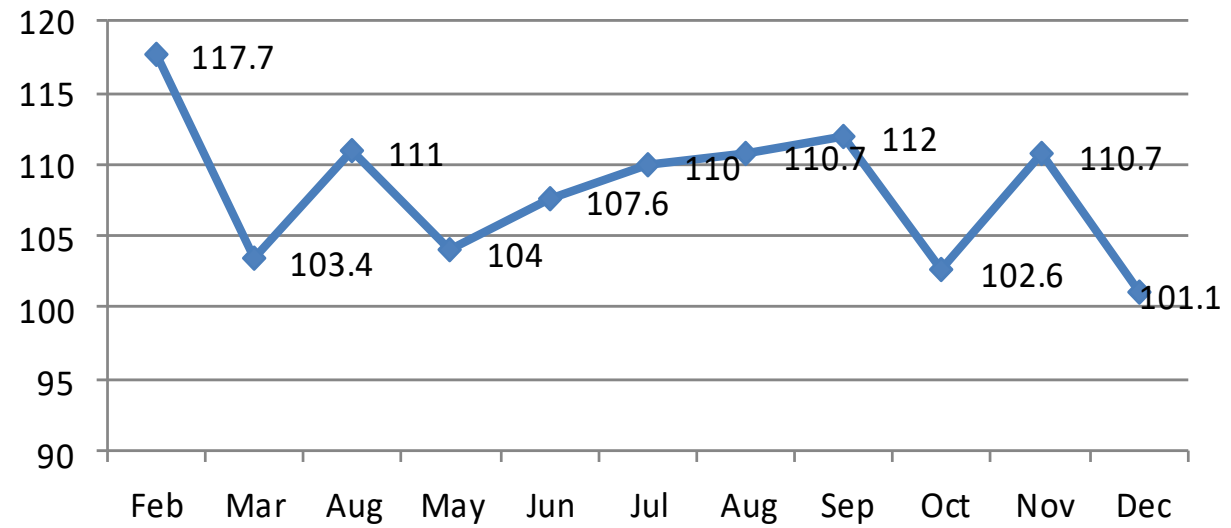

Graph 1. Average monthly Hb level within HD study population 
Graph 1 displays the mean hemoglobin values during one-year follow-up. Considering the whole study population, mean $\mathrm{Hb}$ was maintained within the target range most of the time.

However, apparently stable mean $\mathrm{Hb}$ levels in an overall study population can hide the occurrence of intra-individual variability in many patients which is shown in Figure 1.

Narrow hemoglobin target values resulted in frequent dose adjustments including the ESA with- drawal and consequent substantial hemoglobin fluctuations. During the one-year follow-up, there were an average 5.6 ESA dose changes, and $61 \%$ of patients had $\geq$ three dose changes (Graph 2). Regarding the number of hemoglobin cycling episodes, it was noticed that only $23.4 \%$ of patients had never experienced hemoglobin cycling during the study period.

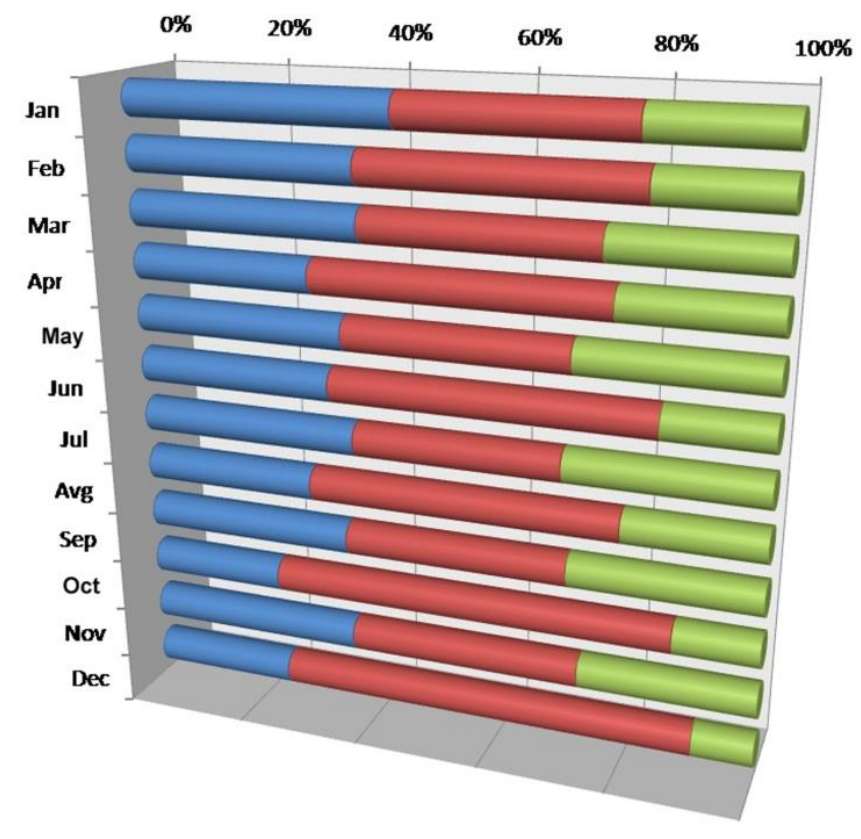

$\square \mathrm{Hb}<\mathbf{1 0}$

$\square \mathbf{1 0} \leq \mathrm{Hb} \leq 11$

$\square \mathrm{Hb}>11$

Figure 1. Distribution of monthly $\mathrm{Hb}$ levels in $\mathrm{HD}$ patients: below/within/above target percentage bar plot

\section{Number of patients/Number of ESA dose changes per year}

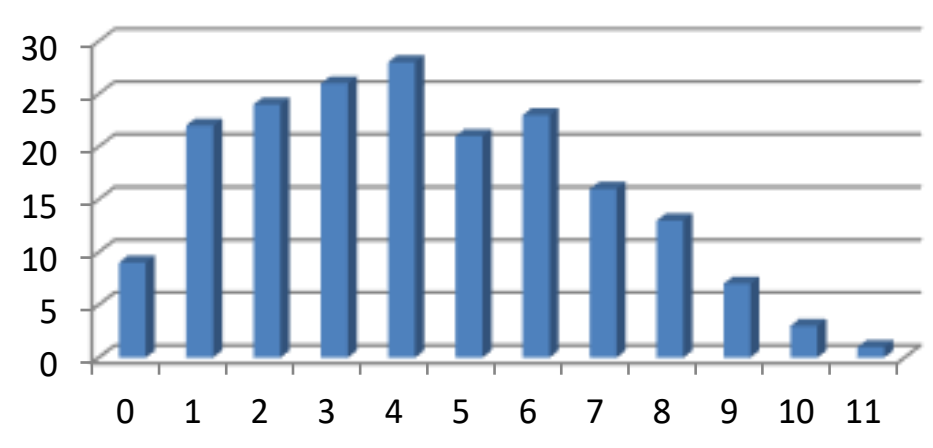

Number of patients

Graph 2. Number of ESA dose changes per year 
Simultaneously, out of 193 patients, hemoglobin excursions were recorded in 145 (76.6\%). These patients experienced a mean of $2.42 \pm 2.7 \mathrm{Hb}$ excursions (defined as half of one full $\mathrm{Hb}$ cycle) per year, and the mean amplitude of excursions was $2.13 \pm 0.76 \mathrm{~g} / \mathrm{dL}$, while the average length of hemoglobin excursion was $8.2 \pm 2.7$ weeks. A total of 460 hemoglobin excursions were documented.
Regarding the fluctuating pattern in hemoglobin levels over time, we recorded 188 excursions with $\mathrm{Hb}$ above the expected value ( $\mathrm{Hb}$ values $>125 \mathrm{~g} / \mathrm{dl}$ ) and 272 downward $\mathrm{Hb}$ excursions with $\mathrm{Hb}$ values $<85 \mathrm{~g} / \mathrm{dl}$ (Graph 3).

Finally, the study population was divided into two groups according to the presence or absence of $\mathrm{Hb}$ cycling during the follow-up time (Table 2).

\section{Number of patients/Number of $\mathrm{Hb}$ excursions}

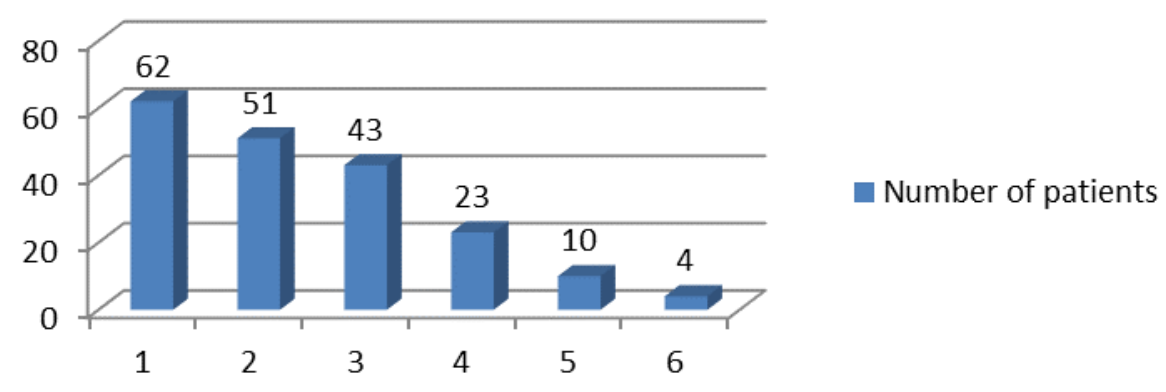

Graph 3. Number of $\mathrm{Hb}$ excursions in $\mathrm{HD}$ patient treated with $\mathrm{ESA}$

Table 2. Characteristics of patients with or without hemoglobin cycling

\begin{tabular}{||l|c|c|c||}
\cline { 2 - 4 } \multicolumn{1}{l||}{} & $\begin{array}{c}\text { Patients with } \\
\text { Hb variability }\end{array}$ & $\begin{array}{c}\text { Patients without } \\
\text { Hb variability }\end{array}$ & p \\
\hline Number of patiets & 148 & 45 & 0.578 \\
\hline Gender (males \%) & 60.7 & 61.7 & 0.612 \\
\hline Age (years) & $61.32 \pm 11.42$ & $63.71 \pm 12.02$ & 0.002 \\
\hline AVF (\%) & 78.74 & 91.57 & 0.05 \\
\hline HD vintage (months) & $59.76 \pm 62.27$ & $58.04 \pm 55.13$ & 0.246 \\
\hline DM (\%) & 19.2 & 21.8 & 0.065 \\
\hline HTA (\%) & 65.12 & 69.33 & $<0.001$ \\
\hline Frequency of ESA dose change & $4.22 \pm 2.44$ & $2.95 \pm 2.58$ & 0.822 \\
\hline ESA dose (IU/kg/week) & $70.08 \pm 47.37$ & $63.37 \pm 55.52$ & 0.004 \\
\hline Hb (g/dl) & $101.53 \pm 10.39$ & $104.87 \pm 4.57$ & 0.003 \\
\hline Feritin (ng/mL) & $639.37 \pm 488.51$ & $531.62 \pm 319.78$ & 0.758 \\
\hline TSAT (\%) & $30.82 \pm 13.87$ & $35.46 \pm 32.87$ & $<0.001$ \\
\hline CRP (mg/l) & $14.32 \pm 2.05$ & $7.14 \pm 2.4$ & 0.17 \\
\hline Kt/V & $1.31 \pm 0.4$ & $1.35 \pm 0.2$ & 0.002 \\
\hline PTH (pg/ml) & $573.8 \pm 496.2$ & $241.6 \pm 319$ & \\
\hline
\end{tabular}

Abbreviation: $\mathrm{Hb}$, hemoglobin; HD-hemodialysis; DM-Diabetes mellitus; HTA-hypertension; ESA erythropoiesis stimulating agents; TSAT-transferrin saturation; CRP, C-reactive protein; PTH, parathormone. 
The change in $\mathrm{Hb}$ level was not affected by the gender, age, weekly ESA dose or the presence of diabetes or hypertension. However, the frequency of ESA dose change ( $p<0,001)$, inflammation ( $p<$ $0.001)$, type of vascular access $(p=0.002)$ and secondary hyperparathyroidism ( $p=0.002)$ significantly influenced hemoglobin variability.

Six variables with the highest correlation coefficient in the univariate analysis were included in the multiple linear regression analysis to determine the significant predictors of $\mathrm{Hb}$ variability. The results show that $\mathrm{Hb}$ variability was associated with ESA dose change (OR 1.56;95\% CI 1.29-2.04, $\mathrm{p}<$ 0.001 ), CRP (OR 1.73; 95\% CI 1.22-1.99, $\mathrm{p}<$ 0.001 ) and vascular access type (OR 2.13; 95\% CI 1.56-3.18, $\mathrm{p}=0.033$ ) (Table 3).
Of 193 patients 31 of them (16.6\%) died in $1 \mathrm{~A} 2$ month study period. The effects of hemoglobin fluctuation on mortality were evaluated by logistic regression analysis. Full adjustment was made with variables such as age, vascular access type, CRP, $\mathrm{Hb}$, dialysis vintage, diabetes, hypertension and ESA dose.

The hazard ratios in HD patients were 1.458 (95\% CI: 1.304-1.771, p < 0.001) for 6-month allcause mortality, 1.424 (95\% CI: 1.231-1.682, Pp < 0.001 ) for 1 -year all-cause mortality after full adjustment (Table 4).

The cumulative 12-months survival rates of the two groups were statistically significant according to the Kaplan-Meier curve ( $p<0.001$ by logrank test) (Graph 4).

Table 3. Independent predictors of hemoglobin variability determined with logistic regression model

\begin{tabular}{||l||c|c|c||}
\hline \multicolumn{1}{|c|}{ Variable } & OR & $\begin{array}{c}\mathbf{9 5 \%} \text { Confidence } \\
\text { Interval }\end{array}$ & p \\
\hline \hline ESA dose changes per patient $(\mathrm{n})$ & 1.56 & $(1.29-2.04)$ & $<0.001$ \\
\hline CRP & 1.73 & $(1.22-1.99)$ & $<0.001$ \\
\hline Vascular access type & 2.13 & $(1.56-3.18)$ & 0.033 \\
\hline
\end{tabular}

Table 4. Prediction of mortality according to $\mathrm{Hb}$ variability in $\mathrm{HD}$ patients***

\begin{tabular}{||c|c|c||}
\cline { 2 - 3 } \multicolumn{1}{c|}{} & Age adjusted OR (95\% CI) & Fully Adjusted OR (95\% CI)*** \\
\hline $\begin{array}{c}\text { 6-months } \\
\text { mortality }\end{array}$ & $1.570(1.341-1.897) \neq$ & $1.458(1.304-1.771) \neq$ \\
\hline $\begin{array}{c}12 \text {-months } \\
\text { mortality }\end{array}$ & $1.420(1.227-1.551) \neq$ & $1.424(1.231-1.682) \neq$ \\
\hline
\end{tabular}

Adjusted by age, vascular access type, CRP, Hb, dialysis vintage, diabetes, hypertension and ESA dose, $\mathrm{CI}$, indicates confidence interval; $\mathrm{HR}$, hazard ratio; OR, odds ratio. $\neq \mathrm{p}<0.001$

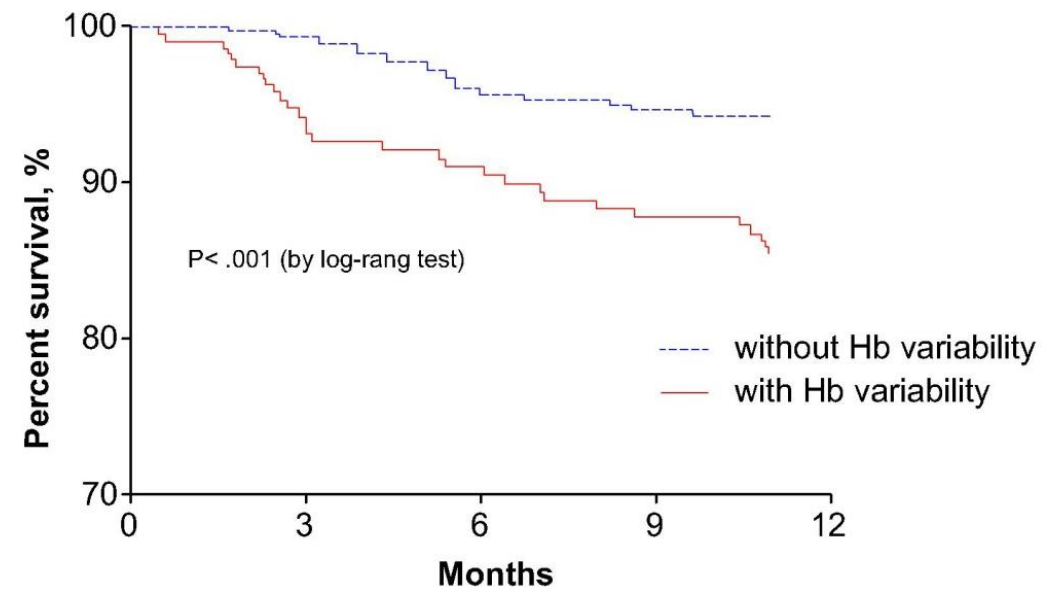

Graph 4. The Kaplan Meier curve for the cumulative 12-month survival rates between patients with and without $\mathrm{Hb}$ variability. Log-rank test shows significant difference between two groups statistically. 


\section{Discussion}

Keeping the constant $\mathrm{Hb}$ levels is obligatory to ensure continuous and sufficient oxygen delivery to tissues. In healthy subjects, individual variation in the $\mathrm{Hb}$ level occurs within the range of normal values, usually does not exceed $1 \mathrm{~g} / \mathrm{dL}$ and have no clinical significance. However, for hemodialysis patients, substantial variability in the $\mathrm{Hb}$ level over time is not uncommon. Fluctuations in the $\mathrm{Hb}$ levels provoke repeated episodes of relative ischemia and tissue hypoxia, which may result in organ dysfunction or injury (10).

The key finding of this study is confirming that $\mathrm{Hb}$ cycling frequently occurs in hemodialysis patients. Over a one-year period, only $25 \%$ of patients using ESA had stable $\mathrm{Hb}$ levels within a target range of $10-11 \mathrm{~g} / \mathrm{dL}$. This reflects the difficulty of maintaining $\mathrm{Hb}$ levels within a narrow range as recommended by the most recent guidelines and hemoglobin management still remained a substantial challenge in the care of hemodialysis patients, with almost all patients moving between categories over fairly short time periods. The finding that patients receiving ESA had high variability agrees with previous studies and points to the current practice of prescribing ESA as one of the causes of $\mathrm{Hb}$ variability $(12-14)$. The other possible factors that might affect patients' $\mathrm{Hb}$ variability were summarized in a review by KalantarZadeh and Aronoff (15). These authors concluded that drug-related factors, patient demographics, iron deficiency, infections, inflammation, malignancies, and reimbursement-related factors all had an impact on $\mathrm{Hb}$ variability. Of these multiple factors, the ESA dose was the most actionable factor in the management of anemia for patients on dialysis therapy.

In the present study, we observed three major determinants of $\mathrm{Hb}$ fluctuation. The first was a frequent change in ESA dose. A positive correlation was seen between ESA dose change and amplitude of $\mathrm{Hb}$ excursion, implying that dose changes were causal, rather than reactive. That finding has also been published by others (16) and strongly implicates current dosing strategies and anemia management protocols in the pathogenesis of $\mathrm{Hb}$ cycling. Interestingly, compared with dose increases, dose reductions seemed to be a stronger predictor of cycling. We noted 272 downward $\mathrm{Hb}$ excursions. The $\mathrm{Hb}$ decline was mostly the consequence of ESA withdrawal (in $78.3 \%$ of cases) and dose reduction in $15 \%$.

Evidence suggests that inflammation is an important factor associated with $\mathrm{Hb}$ variability. In a retrospective study of 225 hemodialysis patients, high CRP values were associated with less stable $\mathrm{Hb}$ levels (17). Likewise, Barany et al. reported a significant correlation between $\mathrm{Hb}$ variability and CRP levels (18). Similarly to these findings, we observed that higher CRP values significantly influence $\mathrm{Hb}$ variability. These results provide supporting evidence that inflammation can trigger hemoglobin variability. Thus, ESA dosage should be regularly reviewed, and patients should be monitor closely in the presence of inflammatory conditions.

Whereas the weekly dose of ESA was comparable regardless of the vascular access used, the weekly dose of ESA used in the patients with central vein catheter (CVC) was significantly higher than that used in those with AVF. This observation is consistent with other studies that indicate that CVC use as vascular accesses is associated with the need for higher doses of ESA secondly to blood loss during dialysis and possible catheter-related infections (19). Besides, the type of vascular access had an impact on $\mathrm{Hb}$ variability, possibly via intercurrent inflammation.

Studies about the clinical significance of $\mathrm{Hb}$ variability have been increased but results were conflicting. Regidor et al. (20) noticed that patients with $\mathrm{Hb}$ fall greater than $2 \mathrm{~g} / \mathrm{dL}$ had the greatest mortality risk when compared with patients who showed $\mathrm{Hb}$ fall lower than $0.8 \mathrm{~g} / \mathrm{dL}$. In a cohort of 34,963 prevalent HD patients, Yang et al. (21) demonstrated that per every $1 \mathrm{~g} / \mathrm{dL}$ increase of $\mathrm{Hb}$ variability, there is a $33 \%$ increase in mortality risk. On the contrary, Zeynep et al. found that hemoglobin variability has a modest association with morbidity and all-cause mortality in ESA treated dialysis patients (22). Persistently or transiently low $\mathrm{Hb}$ levels have also been associated with hospitalization and death $(9,23,24,25)$, as have downward $\mathrm{Hb}$ excursions (25). In our study, we likewise observed that $\mathrm{Hb}$ fluctuation was an independent determinant of mortality, which is in accordance with the recent study of Lin et al. (26). They also demonstrated that high $\mathrm{Hb}$ variability is an independent risk factor for cardiovascular mortality in HD patients and might influence the cardiac function.

Although the direct effects of $\mathrm{Hb}$ variation on patient outcome are still not fully understood, it is evident that large or frequent fluctuations are undesirable. Low $\mathrm{Hb}$ levels have a negative impact on symptoms and quality of life for patients; they also increase the requirement for blood transfusions. The myocardium may be particularly vulnerable to hemoglobin fluctuation because it has to compensate for periods of reduced oxygen delivery with increased output and myocardial cell growth. Hemoglobin levels higher than current target ranges may be associated with worse cardiovascular outcomes (7, 8), and higher $\mathrm{Hb}$ levels maintained with higher ESA doses have a significant cost implication. More frequent $\mathrm{Hb}$ fluctuations outside of target ranges require more clinician time to determine response in terms of ESA dose adjustment or of intravenous iron dosing.

\section{Conclusion}

Hemoglobin management remained a substantial challenge in the care of hemodialysis patients, with almost all patients moving between different hemoglobin categories over fairly short time periods. Our study demonstrates that both inflammation and the frequent changes of ESA dose were the major predictors of hemoglobin variability. The current ESA reimbursement practice demands constant adjustments of the ESA doses. The question is whether modification of treatment policies can contribute to reducing cycling and whether this influences the outcome. To answer this question, further studies are needed. 


\section{References}

1. KDIGO clinical practice guideline for anemia in chronic kidney disease. Kidney Int Suppl 2012;2:279-335.

2. Baris A. The Relationship between Depressive Symptoms and Erythropoietin Resistance in Stable Hemodialysis Patients with Adequate Iron Stores. Int J Artif Organs 2013;36:314-19.[CrossRef] [PubMed]

3. Spinowitz $B$, Pecoits-Filho R, Winkelmayer WC, Pergola $\mathrm{PE}$, Rochette $\mathrm{S}$, Thompson-Leduc $\mathrm{P}$ et al. Economic and quality of life burden of anemia on patients with CKD on dialysis: a systematic review. J Med Econ 2019;[CrossRef] [PubMed]

4. Locatelli F, Bárány $P$, Covic A, De Francisco A, Del Vecchio $L$, Goldsmith $D$ et al. Kidney disease: improving global outcomes guidelines on anaemia management in chronic kidney disease: a European renal best practice position statement. Nephrol Dial Transplant 2013;28:1346-59. [CrossRef] [PubMed]

5. Macdougall IC. Steering Committee of the CREATE trial; CREATE Study Group: CREATE: new strategies for early anaemia management in renal insufficiency. Nephrol Dial Transplant 2003;18:13-16.[PubMed]

6. Singh AK, Szczech L, Tang KL, Barnhart H, Sapp S, Wolfson $\mathrm{M}$ et al; CHOIR Investigators: Correction of anemia with epoetin alfa in chronic kidney disease. N Engl J Med 2006;355:2085-98.[CrossRef] [PubMed]

7. Brunelli SM, Lynch KE, Ankers ED, Joffe MM, Yang W, Thadhani RI et al. Association of hemoglobin variability and mortality among contemporary incident hemodialysis patients. Clin J Am Soc Nephrol 2008; 3:173340.[CrossRef] [PubMed]

8. Weinhandl ED, Peng Y, Gilbertson DT, Bradbury BD, Collins AJ. Hemoglobin variability and mortality: Confounding by disease severity. Am J Kidney Dis 2011; 57:255-65.[CrossRef] [PubMed]

9. Ebben JP, Gilbertson DT, Foley RN, Collins AJ. Hemoglobin level variability: Associations with comorbidity, intercurrent events, and hospitalizations. Clin J Am Soc Nephrol 2006;1:1205-10. [CrossRef] [PubMed]

10. Zhao L, Hu C, Cheng J, Zhang P, Jiang H, Chen J. Haemoglobin variability and all-cause mortality in haemodialysis patients: A systematic review and meta-analysis. Nephrology 2019;24(12):1265-1272. [CrossRef] [PubMed]

11. Fishbane S, Berns JS. Evidence and implications of haemoglobin cycling in anemia management. Nephrol Dial Transplant 2007;22:2129-32. [CrossRef] [PubMed]

12. Spiegel DM. Hemoglobin variability in chronic kidney disease: A cross-sectional study. Am J Med Sci 2009; 337:340-3.[CrossRef] [PubMed]

13. Minutolo $R$, Chiodini $P$, Cianciaruso $B$, Pota A, Bellizzi $V$, Avino D et al. Epoetin therapy and hemoglobin level variability in nondialysis patients with chronic kidney disease. Clin J Am Soc Nephrol 2009;4:552-9. [CrossRef] [PubMed]

14. Boudville NC, Djurdjev O, Macdougall IC, de Francisco AL, Deray G, Besarab A et al. Hemoglobin variability in nondialysis chronic kidney disease: examining the association with mortality. Clin J Am Soc Nephrol 2009;4:1176-82.[CrossRef] [PubMed]

15. Kalantar-Zadeh K, Aronoff GR. Hemoglobin variability in anemia of chronic kidney disease. J Am Soc Nephrol 2009;20:479-87.[CrossRef] [PubMed]

16. Fishbane S, Berns JS. Hemoglobin cycling in hemodialysis patients treated with recombinant human erythropoietin. Kidney Int 2005;68:1337-43. [CrossRef] [PubMed]

17. de Francisco $A$, Stenvinkel $P$, Vaulont $S$. Inflammation and its impact on anaemia in chronic kidney disease: from haemoglobin variability to hyporesponsiveness. NDT Plus 2009;2:i18-i26. [CrossRef] [PubMed]

18. Barany P, Carrero JJ, Snaedal J'onsd'ottir S. Variability of hemoglobin $(\mathrm{Hb})$ levels in relation to inflammatory status and iron metabolism in hemodialysis (HD) patients (Pts). Proceedings of the American Society of Nephrology Annual Congress; 2006; San Diego, USA.

19. Roberts TL, Obrador GT, St Peter WL, Pereira BJ, Collins AJ. Relationship among catheter insertions, vascular access infections, and anemia management in hemodialysis patients. Kidney Int 2004;66:242936. [CrossRef] [PubMed]

20. Regidor DL, Kopple JD, Kovesdy CP, Kilpatrick RD, McAllister $\mathrm{CJ}$, Aronovitz $\mathrm{J}$ et al. Associations between changes in hemoglobin and administered erythropoiesis-stimulating agent and survival in hemodialysis patients. J Am Soc Nephrol 2006;17:1181-91. [CrossRef] [PubMed]

21. Yang W, Israni RK, Brunelli SM, Joffe MM, Fishbane S, Feldman HI. Hemoglobin variability and mortality in ESRD. J Am Soc Nephrol 2007; 18:3164-70. [CrossRef] [PubMed]

22. Zeynep B, Bahar GD, Suleyman K, Emre T, Mehtap $\mathrm{EU}$, Nurhan OAal. Factors Influencing Hemoglobin Variability and Its Association with Mortality in Hemodialysis Patients. Scientific World Journal 2018;18. [CrossRef] [PubMed]

23. Regidor DL, Kopple JD, Kovesdy CP, Kilpatrick RD, McAllister C], Aronovitz J, et al. Associations between changes in hemoglobin and administered erythropoiesis-stimulating agent and survival in hemodialysis patients. J Am Soc Nephrol 2006;17:1181-91. [CrossRef] [PubMed]

24. Gilbertson DT, Ebben JP, Foley RN, Weinhandl ED, Bradbury BD, Collins AJ. Hemoglobin level variability: associations with mortality. Clin J Am Soc Nephrol 2008;3:133-8.[CrossRef] [PubMed]

25. Ishani A, Solid CA, Weinhandl ED, Gilbertson DT, Foley RN, Collins AJ. Association between number of months below K/DOQI haemoglobin target and risk of hospitalization and death. Nephrol Dial Transplant 2008; 23:1682-9. [CrossRef] [PubMed]

26. Lin FJ, Zhang $X$, Huang LS, Ji G, Huang HD, Xie Yet al. Impact of hemoglobin variability on cardiovascular mortality in maintenance hemodialysis patients. Int Urol Nephrol 2018;50:1703-12.[CrossRef] [PubMed] 


\title{
PREVALENCIJA I DETERMINANTE VARIJABILNOSTI HEMOGLOBINA I NJEN UTICAJ NA MORTALITET KOD BOLESNIKA NA HRONIČNOM PROGRAMU HEMODIJALIZE
}

\author{
Zorica Dimitrijević1,2, Branka Mitić1,2, Karolina Paunović ${ }^{1}$, Sonja Šalinger-Martinović ${ }^{2}$
}

${ }^{1}$ Klinika za nefrologiju, Klinički centar Niš, Niš, Srbija

${ }^{2}$ Univerzitet u Nišu, Medicinski fakultet, Niš, Srbija

Kontakt: Zorica Dimitrijević

Njegoševa 52, 18000 Niš, Srbija

E-mail: zorica_mdimitrijevic@yahoo.com

Terapija agensima stimulacije eritropoeze (ASE) predstavlja optimalno lečenje renalne anemije. Međutim, održavanje hemoglobina ( $\mathrm{Hb}$ ) u okviru uskih ciljnih vrednosti ostaje značajan klinički problem, s obzirom na to da tokom primene ASE nivoi Hb obično značajno osciliraju; ovaj fenomen poznat je kao "varijabilnost hemoglobina", a udružen je sa povećanom smrtnošću bolesnika. Naše istraživanje imalo je za cilj da analizira učestalost i uzroke nastanka varijabilnosti hemoglobina kod bolesnika lečenih hemodijalizom (HD) i da proceni njen uticaj na mortalitet bolesnika.

Prospektivnom studijom obuhvaćeno je 193 bolesnika na hroničnoj HD, koji su lečeni ASE. Varijabilnost hemoglobina definisana je kao oscilacija koncentracije $\mathrm{Hb}$ u periodu od najmanje osam nedelja sa amplitudom većom od 1,5 g/dl od zadatih ciljnih vrednosti hemoglobina, koji u Srbiji za bolesnike na HD trenutno iznosi $10 \mathrm{~g} / \mathrm{dl}-11 \mathrm{~g} / \mathrm{dl}$.

Tokom jednogodišnjeg praćenja, bilo je 5,6 modifikacija doze ASE po bolesniku. 23,4\% bolesnika nije imalo značajne oscilacije $\mathrm{Hb}$ tokom studijskog perioda. Ukupno 460 oscilacija (ekskurzija) hemoglobina zabeleženo je kod $76,6 \%$ bolesnika, sa 2,42 ekskurzije $\pm 2,7$ ekskurzija godišnje, prosečne amplitude $2,13 \mathrm{~g} / \mathrm{dL} \pm 0,76 \mathrm{~g} / \mathrm{dL}$ i prosečne dužine trajanja 8,2 nedelje $\pm 2,7$ nedelja. Na osilaciju $\mathrm{Hb}$ nije uticala starost, pol, nedeljna doza ASE, kao ni prisustvo dijabetesa ili hipertenzije. Međutim, varijabilnost $\mathrm{Hb}$ zavisila je od promena doze ASE, CRP-a i tipa vaskularnog pristupa za HD.

Varijabilnost hemoglobina često se javlja kod bolesnika na HD lečenih ASE, kao posledica prakse učestalih promena doze ASE, prisustva infekcija i vrste vaskularnog pristupa za HD. Ove fluktuacije hemoglobina uticale su na povećanje mortaliteta kod naših bolesnika. Procena rizika za jednogodišnji mortalitet bila je 1,424 (95\% CI: 1,231 - 1,682; P<0,001).

Acta Medica Medianae 2020;59(1):05-13.

Ključne reči: varijabilnost hemoglobina, agensi stimulacije eritropoeze, hemodijaliza 